\title{
Hydrological Modeling of Aguibat Ezziar Watershed (Morocco), Comparative Study of Two Different Hydrological Models
}

\author{
Mourad Khattatı ${ }^{*}$, Mostapha Serroukh ${ }^{1}$, Ismail Rafık ${ }^{1}$, Hakim Mesmoudı1, \\ Hassane Brırhet ${ }^{2}$, Yassine Bouslıhım ${ }^{3}$, Fatima Hara ${ }^{4}$ \\ ${ }^{1}$ Research Team ERGO, Faculty of Science, Abdelmalek Essaadi University, Tetouan, Morocco \\ ${ }^{2}$ Faculty of Science and Technology, Sidi Mohammed Ben Abdellah University, Fes, Morocco \\ ${ }^{3}$ Faculty of Science and Technology, 1st Hassan University, Settat, Morocco \\ ${ }^{4}$ Scientific Institute, Mohammed V University, Rabat, Morocco \\ Email: "khattati.mourad@hotmail.fr
}

Received 5 January 2016; accepted 16 February 2016; published 19 February 2016

Copyright (C) 2016 by authors and Scientific Research Publishing Inc.

This work is licensed under the Creative Commons Attribution International License (CC BY). http://creativecommons.org/licenses/by/4.0/

(c) (7) Open Access

\begin{abstract}
This study aims to compare the performance of two hydrological models, conceptual (HEC-HMS) and spatial (ATHYS) on the Aguibat Ezziar watershed. The comparative analysis is based on the performances of simulation in terms of Nash-Sutcliffe and RSR. The study requires the collection of a series of data as inputs models namely rainfall data, water quantity, soil occupation, DTM and requires also a calibration in order to evaluate these models in validation phase. The simulation results were obtained from the validation phase aiming to replicate the operation of watershed Aguibat Ezziar, and present a suitable adjustment perspective of the observed hydrograph. These results show that the objective is achieved and a model distributed like ATHYS plays an effective role to improve the efficiency and present a high advantage in anticipation of runoff volume comparing with other models.
\end{abstract}

\section{Keywords}

Spatial Modeling, Distributed Model, Conceptual Model, Hydrology, ATHYS, HEC-HMS

\section{Introduction}

Recent years have shown that the water resource mobilization reached a limit, that why it is essential now that ${ }^{*}$ Corresponding author.

How to cite this paper: Khattatı, M., Serroukh, M., Rafık, I., Mesmoudı, H., Brırhet, H., Bouslıhım, Y. and Hara, F. (2016) Hydrological Modeling of Aguibat Ezziar Watershed (Morocco), Comparative Study of Two Different Hydrological Models. Journal of Geographic Information System, 8, 50-56. http://dx.doi.org/10.4236/igis.2016.81005 
this vital resource is managed in an efficient and sustainable manner. Hydrological models are tools to reproduce the operation of water systems, computing a period of rate return data for the design of a hydraulic structure, determination of a flood of a project, real-time flow forecasting on streams [1]. Managing water resources is mostly required at watershed scale [2] given that is the basic hydrologic unit where can be studied the heterogeneity and complexity of processes and interactions linking land surface, climatic factors and human activities [3]. The objective of this study on Aguibat Ezziar watershed is to compare and analyze the dynamics of watershed functioning with the reconstitution of river flow at outlet (Station Aguibat Ezziar). The simulation of water intake in the hydrological station Aguibat Ezziar has been done with the use of a hydrological ATHYS model (Atelier Hydrologique Spatialisé) and HEC-HMS (Hydrologic Modeling System). However, the objective is tested the adaptability and ensures a good performance of these models. In this work, the time step of modeling is daily, this choice due to compare modeled flows with occasional discharge measurements on the hydrometric Aguibat Ezziar station.

\section{Study Area}

The Aguibat Ezziar watershed covers an area of $3640 \mathrm{~km}^{2}$ and an elongated shape. It is located at the northwest of the Bouregreg watershed north central Morocco (Figure 1).

Aguibat Ezziar watershed is situated between an elevation ranging from $1615 \mathrm{~m}$ to $80 \mathrm{~m}$ at downstream of Bouregreg watershed. Between 1977-2004, the minimum annual rainfall is $336 \mathrm{~mm} /$ year in Lala Chafia station, while the maximum is $434 \mathrm{~mm} / \mathrm{year}$ in Tsalat station. Furthermore, the annual and monthly average is respectively $394 \mathrm{~mm}$ and $39 \mathrm{~mm}$ (Figure 2).

\section{Presentation of Models}

ATHYS (ATelier Hydrologique Spatialisé) is rainfall-runoff transformation model, developed by the Research Institute for Development (IRD) of Montpellier. The basic principles of ATHYS are a hydrological environment for distributed modeling, including a series of models, DEM processing, hydrological and rainfall data and geographical display, spatial data interpolation. The flow generated for a rain event (rainfall-runoff transformation) is calculated for each cell, the amount of rain is estimated by the production model which will contribute to runoff. The transfer model calculated the hydrograph produced by each watershed outlet, this calculation is made

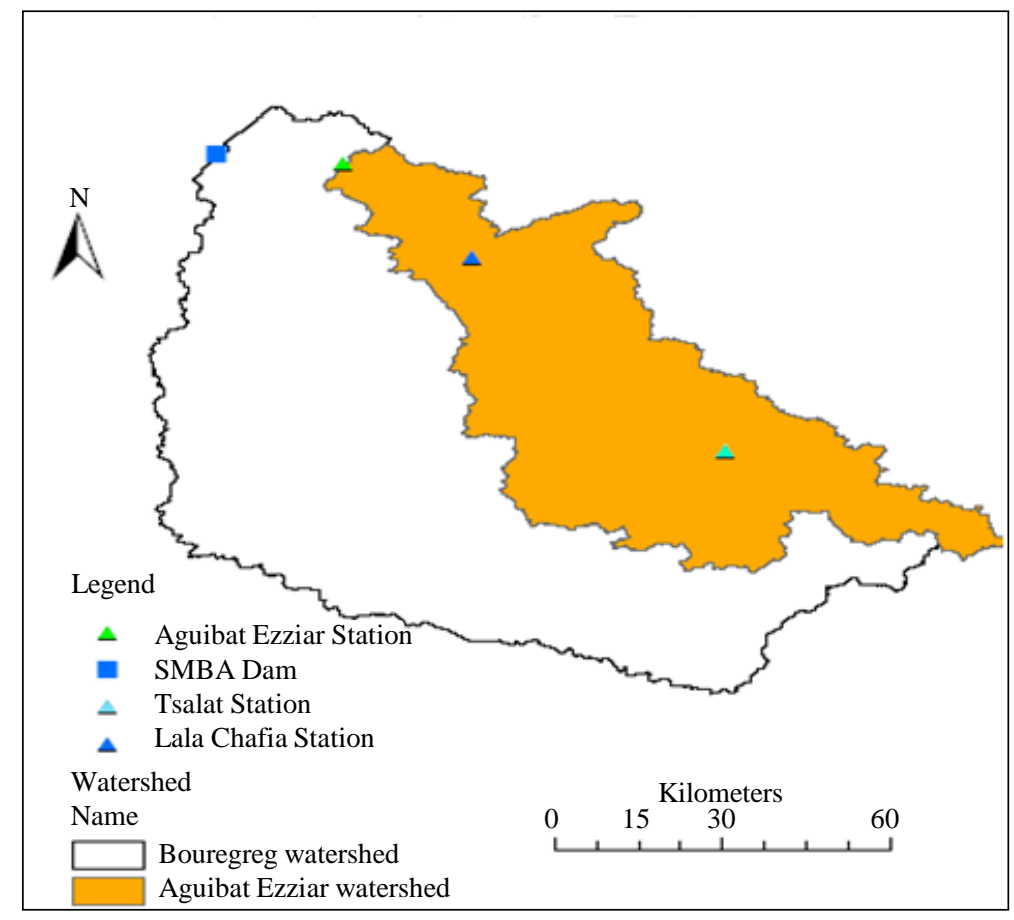

Figure 1. Map situation of Aguibat Ezziar watershed. 


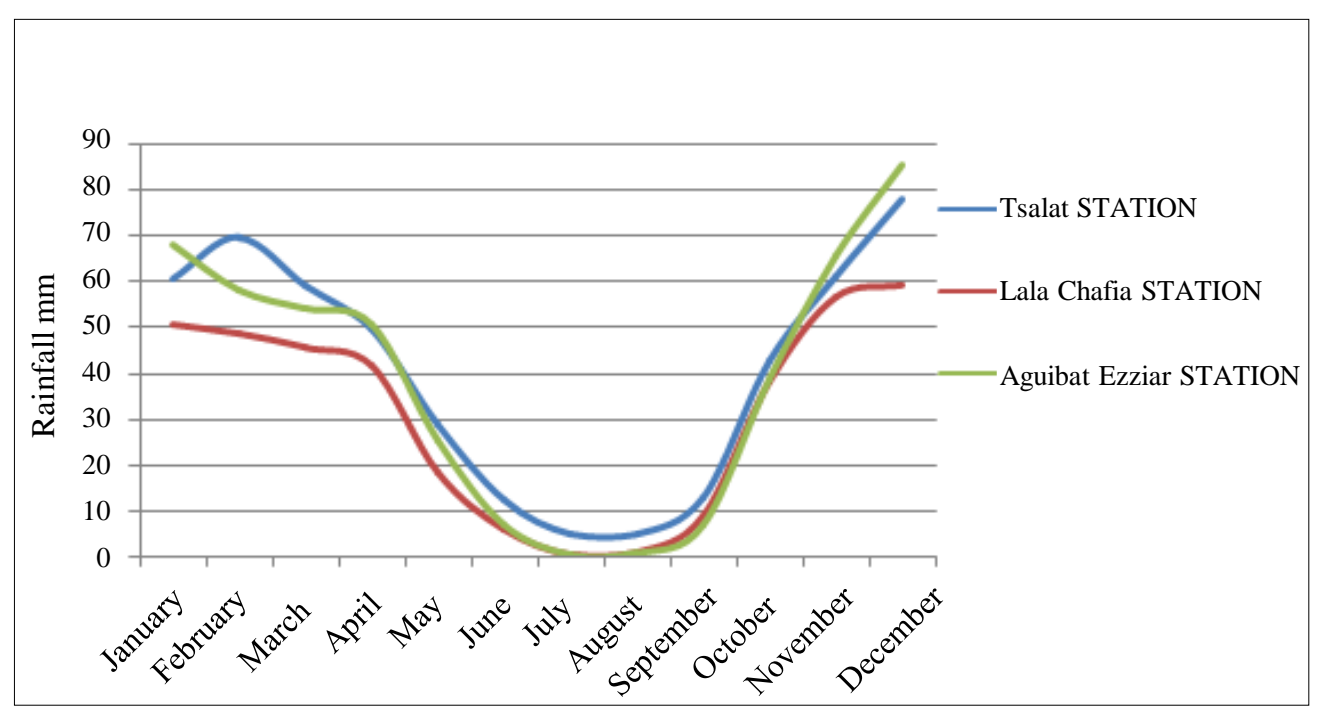

Figure 2. Average monthly rainfall in Aguibat Ezziar watershed.

from the result obtained under the production function. The HEC-HMS is a reliable model developed by the US Army Corps of Engineers that could be used for many hydrological simulations [4]. To facilitate continuous hydrologic modeling, a soil moisture accounting SMA model has been incorporated in HEC-HMS [5]. The model includes many traditional hydrologic analysis procedures such as event infiltration, unit hydrographs [6], and hydrologic routing. Both models have application limits is that they use a limited number of functions.

\section{Methodology and Data Processing}

Both models are used to simulate the flow rates daily time in Aguibat Ezziar station from 1996 to 2003. The calibration and validation period is respectively 1996-1999 and 2000-2003. To estimate the parameters of production and transfer models, a manual procedure by the sensitivity analysis had been used. From input data (DTM, precipitation), the hydrological model ATHYS is used to define the daily runoff flow for each cells of Aguibat Ezziar watershed, and also to obtain the drainage network, slope classes...etc. From the effective rainfall, SCS and Top Model functions define the runoff depth. Moreover, Unit hydrograph transfer function calculates the flows for each sub basins outlet, identified as nodes calculation (Tsalat, Lala Chafia and Aguibat Ezziar). The DEM used is a set of elevation points (three coordinates, $\mathrm{x}, \mathrm{y}$ and $\mathrm{z}$ ) located every $90 \mathrm{~m}$. The topography is reconstructed by the assembly of these points (Figure 3). The sub-mentioned data helped to define the slope classes (Figure 4), drainage directions (Figure 5), drainage network, sub basins (Figure 6).

In this study, three different production classes have been identified from the topography (slopes), as a file reclassified between 459 classes of natural slopes. Low and middle runoff zone correspond to the plains with slopes from 0 to $200 \mathrm{~m} / \mathrm{km}$, while the high runoff zone corresponds to the high slopes mainly on reliefs.

Climatologically information is accurately known in each station. This information must be spatializing on the catchment area. The method of Thiessen polygons was used to define the influence's area for each station (Table 1).

Table 2 shows the breakdown of the areas of Aguibat Ezziar watershed based in the production classes.

The area of high runoff concerns only $7.31 \%$ of the whole watershed area. This area corresponds to the reliefs with bare soil (and/or) with high slopes.

Data preparation for HEC-HMS model was performed manually for the three stations. The SCS Curve Number function is used to model the losses, and is based on knowledge of the type and land use. Runoff modeling is made by the SCS unit hydrograph model that integrates the coefficient Lag Time which can be theoretically determined by the formula " $0.6 \times$ concentration times". To evaluate ours models two statistic coefficients were adopted: Nash-Sutcliffe efficiency coefficient (NSE, Equation (1)) [7] represented the ratio of the residual variance and the variance of the observed flow [8] and RMSE-observations standard deviation ratio (RSR, Equation (2)) [9]. The formulas of these coefficients are given in the following equations. 


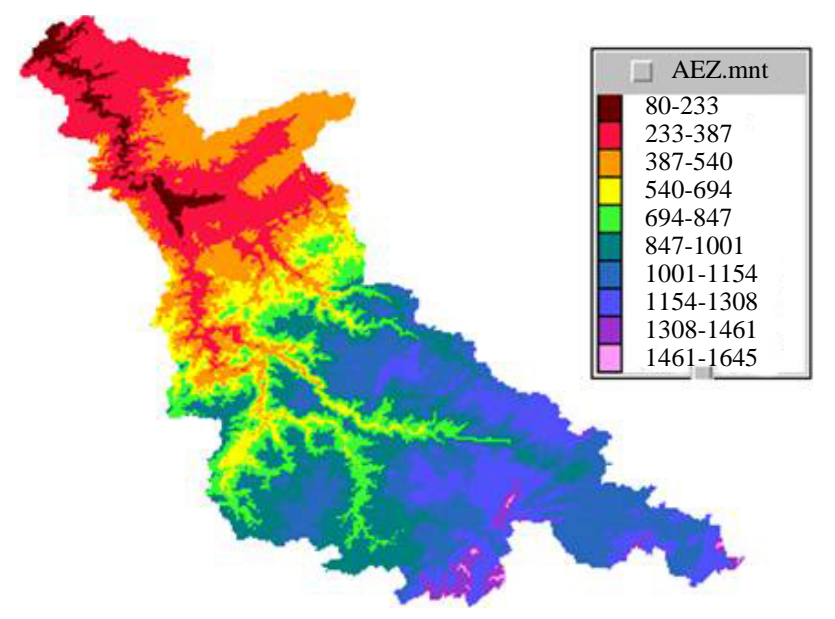

Figure 3. Map of altitudes.

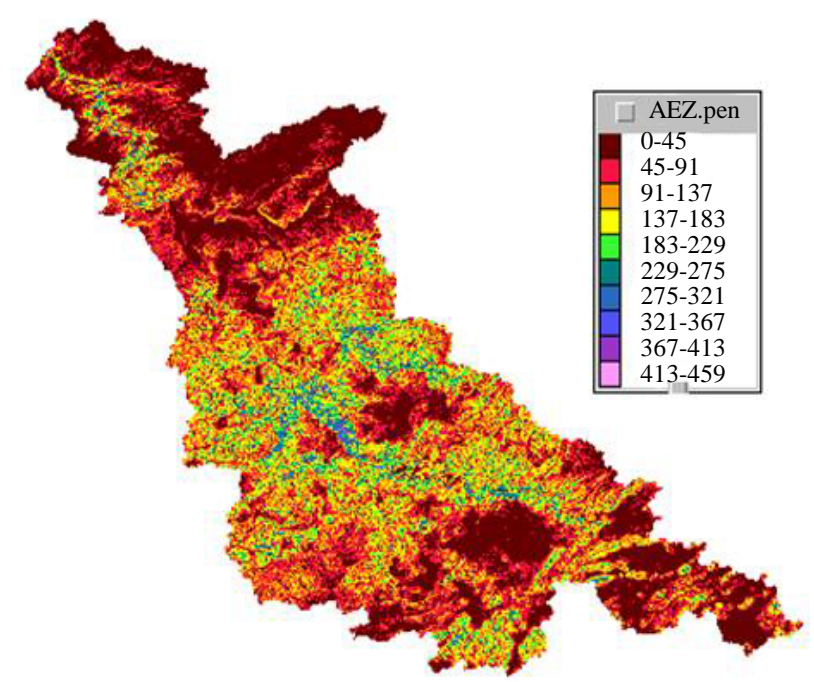

Figure 4. Slope classes.

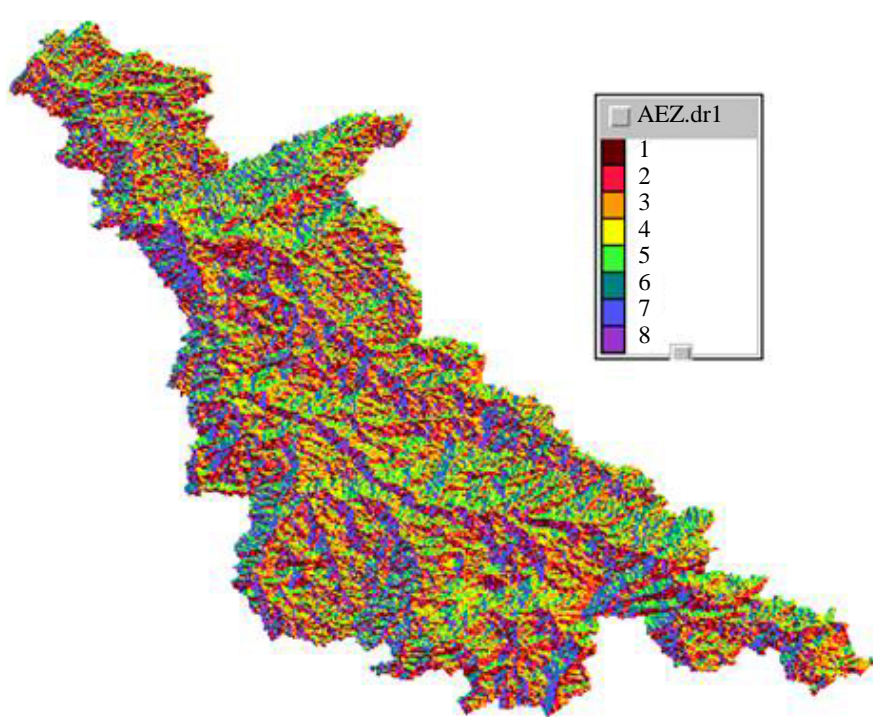

Figure 5. Drainage directions. 


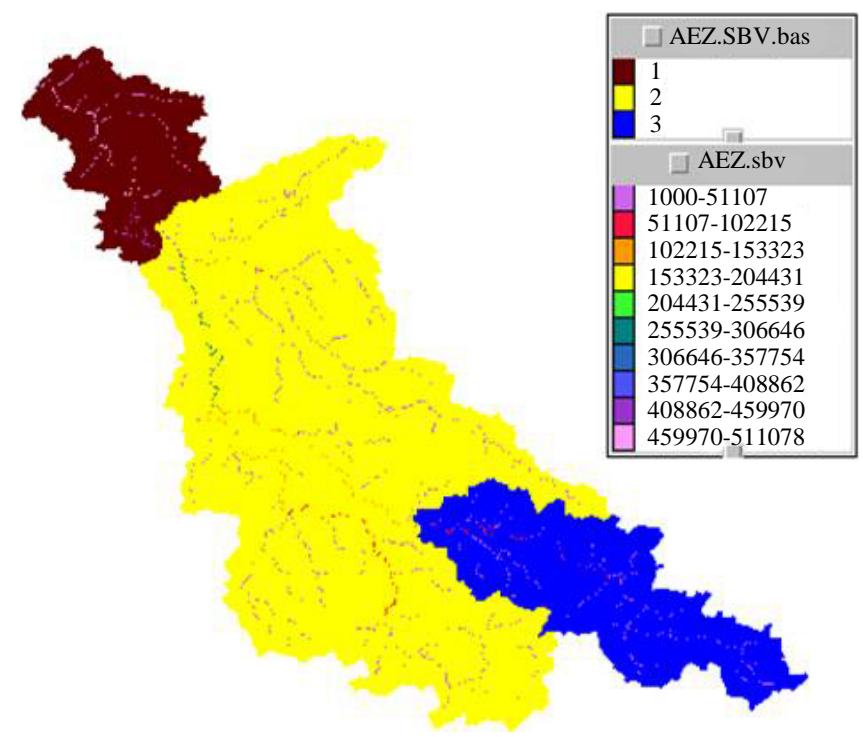

Figure 6. Hydrographic network \& sub basins.

Table 1. Weight stations by Theissen Method.

\begin{tabular}{cccc}
\hline Station & Thiessen coefficient & Area $\left.\mathbf{( K m}^{\mathbf{2}}\right)$ & Extent $\%$ \\
\hline Tsalat & 0.658 & 2395 & 65.90 \\
Lala Chafia & 0.296 & 1077 & 29.60 \\
Aguibat Ezziar & 0.045 & 164 & 4.50 \\
\hline
\end{tabular}

Table 2. Production class.

\begin{tabular}{ccc}
\hline Production class & Area $\left.\mathbf{( k m}^{\mathbf{2}}\right)$ & Extent $\%$ \\
\hline 1-Low runoff & 1331 & 36.57 \\
2-Middle runoff & 2043 & 56.13 \\
3-Rapid runoff & 266 & 7.31 \\
Total & $\mathbf{3 6 4 0}$ & $\mathbf{1 0 0}$ \\
\hline
\end{tabular}

$$
\begin{gathered}
N S E=1-\left[\frac{\sum_{i=1}^{n}\left(Y_{i}^{\text {obs }}-Y_{i}^{\text {sim }}\right)^{2}}{\sum_{i=1}^{n}\left(Y_{i}^{\text {obs }}-Y_{i}^{\text {mean }}\right)^{2}}\right] \\
R S R=\frac{\sqrt{\sum_{i=1}^{n}\left(Y_{i}^{\text {obs }}-Y_{i}^{\text {sim }}\right)^{2}}}{\sqrt{\sum_{i=1}^{n}\left(Y_{i}^{\text {obs }}-Y_{i}^{\text {mean }}\right)^{2}}}
\end{gathered}
$$

$Y_{i}^{\text {obs }}$ : Observed discharges; $Y_{i}^{\text {sim }}$ : Simulated discharges; $Y_{i}^{\text {mean }}$ : Mean of observed discharges.

\section{Results and Discussion}

In this study, the functions used by ATHYS model are SCS and unit hydrograph for the production and transfer function. The sensitivity analysis has allowed to show the best values of the parameter S (SCS) or STO (Top Model) affecting mainly the peak flow. The decline of the hydrograph explained by the emptying time is generally influenced by the DS parameter. Preferentially, we fix the influenced parameters on the general curve of the hydrograph, namely, the diffusion coefficient (K0), the parameters K1 and Alfa, and the transfer speed of V0, which figures on the transfer function (Table 3). 
Table 3. Parameters of production and transfer functions.

\begin{tabular}{|c|c|c|c|c|}
\hline & Parameter & Production class 1 & Production class 2 & Production class 3 \\
\hline \multirow{6}{*}{ 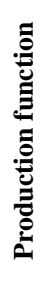 } & $\mathrm{STO}[\mathrm{mm}]$ & 36 & 45 & 49 \\
\hline & INF $\left[\mathrm{mm} \cdot \mathrm{h}^{-1}\right]$ & 10.1 & 9.5 & 9.5 \\
\hline & $\mathrm{F}\left[\mathrm{m}^{-1}\right]$ & 40 & 39.6 & 38.5 \\
\hline & Ds $\left[j^{-1}\right]$ & 0.1 & 0.09 & 0.09 \\
\hline & $\mathrm{CN}$ & A.EZ [78] & L.CHA [69] & TSA [71] \\
\hline & Impervious [\%] & A.EZZIAR [0.33] & L.CHAFIA [0.42] & TSALAT [0.57] \\
\hline \multirow{5}{*}{ 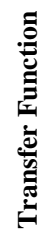 } & $\mathrm{V} 0\left[\mathrm{~m} \cdot \mathrm{s}^{-1}\right]$ & & 1.25 & \\
\hline & Alfa [ad] & & 0.5 & \\
\hline & K0 [ad] & & 0.1 & \\
\hline & $\mathrm{K} 1$ [mn] & & 0.9 & \\
\hline & Lag time [min] & A.EZZIAR [663] & L.CHAFIA [546] & TSALAT [432] \\
\hline
\end{tabular}

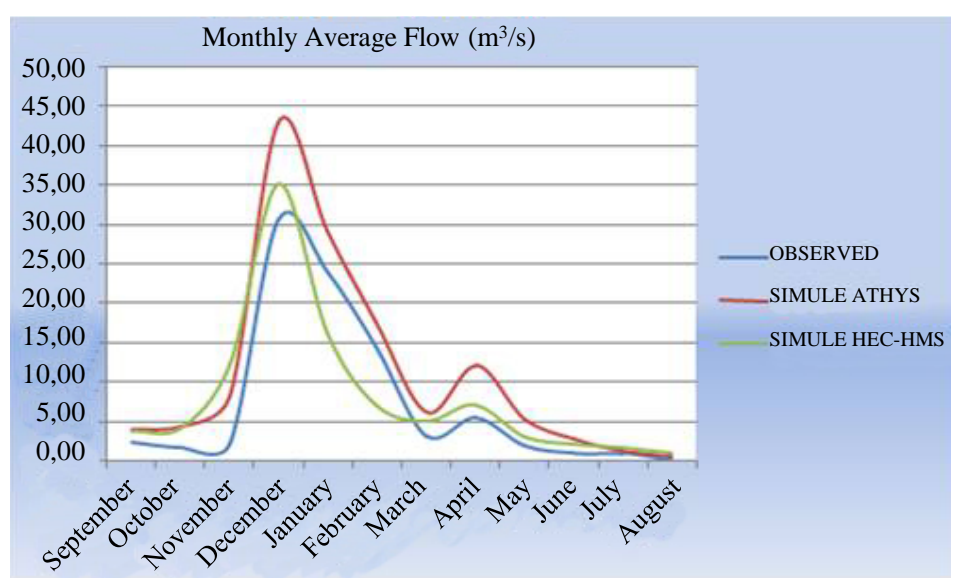

Figure 7. Simulation of mean monthly flows Simulated in Lala Chafia station over (1996-2004).

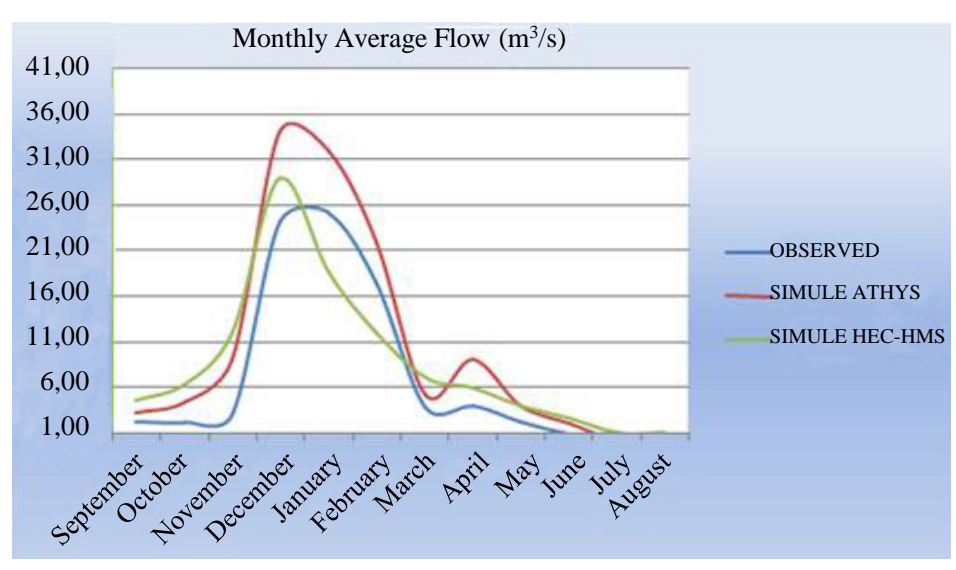

Figure 8. Simulation of mean monthly flows simulated in Aguibat Ezziar station over (1996-2004).

The statistic evaluators showed a good correlation between the monthly observed and simulated river discharge with NSE ATHYS of 0.74, NSE HEC-HMS of 0.73, and RSR ATHYS of 0.39 and RSR HEC-HMS of 0.36 for the calibration period. The validation period revealed good values for NSE 0.73 and RSR 0.32, these model performance for both calibration and validation periods is evaluated as "very good performance rating" 
which is defined by the flowing ranges: 0 to 0.5 for RSR, 0.75 to 1 for NSE (Figure 7 and Figure 8).

The average difference between the observed and simulated monthly total flow is $4 \%$ which confirms a good model's calibration for the daily time step.

Comparing ATHYS and HEC-HMS models on a long event for a long term (24 h) shows that the behavior of the model HEC-HMS is correct with reproductive hydrograph peaks in calibration, in other hand, ATHYS performance at Aguibat Ezziar station is very good for the stability of the model in continuous mode.

\section{Conclusion}

The comparison of models performance (ATHYS and HEC-HMS) on Aguibat Ezziar watershed shows that a distributed model like ATHYS plays an effective role to improve the efficiency and present a high advantage in anticipation of runoff volume. While, The HEC-HMS model is very correct with the estimate peaks and so it can be a more effective model for flood forecasting. This study had demonstrated the utility of distributed model and also showed the ability of ATHYS model to be used to simulate the water quantity in semi-arid regions [10].

\section{Acknowledgements}

The authors thank the Ministry of Energy, Mines, Water and Environment (S.Water-Dr.Brirhet) for providing the data on the studied boreholes.

\section{References}

[1] Mathevet, T. (2005) Quels modèles pluie-débit globaux pour le pas de temps horaire ? Développement empirique et comparaison de modèles sur un large échantillon de bassins versants. Thesis, ENGREF (Paris), Cemagref (Antony), France, 463 p..

[2] Sivapalan, M. (2003) Process Complexity at Hillslope Scale, Process Simplicity at the Watershed Scale: Is There a Connection? Hydrological Processes, 17, 1037-1041. http://dx.doi.org/10.1002/hyp.5109

[3] Fadil, A., Rhinane, H., Kaoukaya, A., Kharchaf, Y. and Bachir, O. (2011) Hydrologic Modeling of the Bouregreg Watershed (Morocco) Using GIS and SWAT Model. Journal of Geographic Information System, 3, 279-289. http://dx.doi.org/10.4236/jgis.2011.34024

[4] Halwatura, D. and Najim, M.M.M. (2013) Application of the HEC-HMS Model for Runoff Simulation in a Tropical Catchment. Environmental Modelling \& Software, 46, 155-162. http://dx.doi.org/10.1016/j.envsoft.2013.03.006

[5] Chu, X. and Steinman, A. (2009) Event and Continuous Hydrologic Modeling with HEC-HMS. Journal of Irrigation and Drainage Engineering, 135, 119-124. http://dx.doi.org/10.1061/(ASCE)0733-9437(2009)135:1(119)

[6] Feldman A. (2000) Hydrologic Modeling System HEC-HMS: Technical Reference Manual. 157.

[7] Nash, J.E. and Sutcliffe, J.V. (1970) River Flow Forecasting through Conceptual Models, Discussion of Principles. Journal of Hydrology, 10, 282-290. http://dx.doi.org/10.1016/0022-1694(70)90255-6

[8] Ayadi, M. and Bargaoui, Z. (1998) Modélisation des écoulements de l’oued Miliane par le modèle CEQUeau. Journal des Sciences Hydrologiques, 43, 741-758. http://dx.doi.org/10.1080/02626669809492170

[9] Singh, J., Knapp, H.V. and Demissie, M. (2004) Hydrologic Modeling of the Iroquois River Watershed Using HSPF and SWAT. Journal of the American Water Resources Association, 41, 343-360. http://dx.doi.org/10.1111/j.1752-1688.2005.tb03740.x

[10] Fadil, A., Rhinane, H., Kaoukaya, A., Kharchaf, Y. and Bachir, O. (2011) Hydrologic Modeling of the Bouregreg Watershed (Morocco) Using GIS and SWAT Model. Journal of Geographic Information System, 3, 288. 